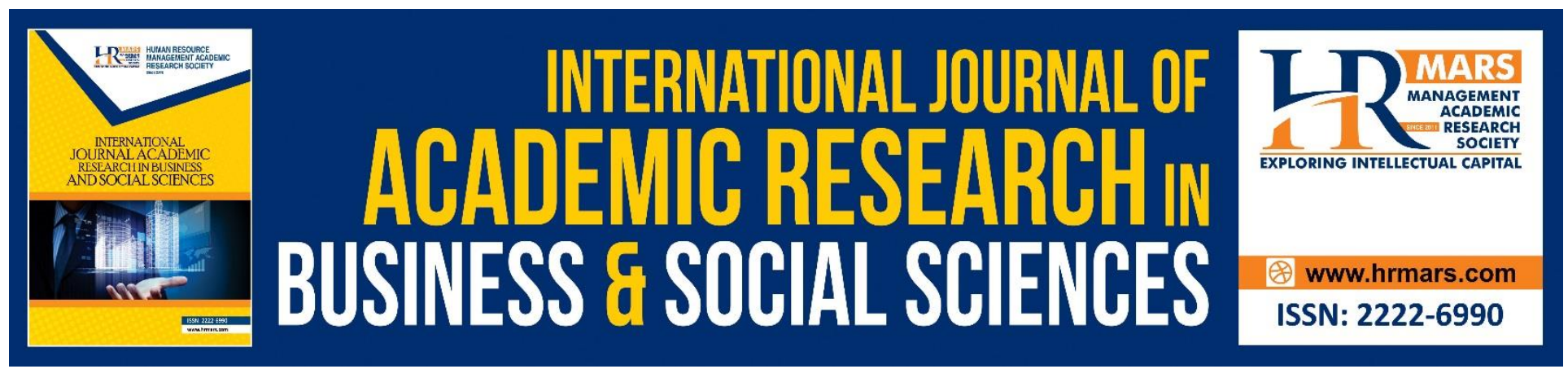

\title{
An Overview of the Malaysian Defence Industry and Way Forward
}

Amirudin Sulaiman, Ruhanas Harun, Mohd Zaini Salleh, Ananthan, S., W. L. Wong, Norlaila Mazura Hj. Mohaiyadin, Syafina Darlila Ahmad Jaid

To Link this Article: http://dx.doi.org/10.6007/IJARBSS/v10-i8/7715 DOI:10.6007/IJARBSS/v10-i8/7715

Received: 19 May 2020, Revised: 21 June 2020, Accepted: 22 July 2020

Published Online: 26 August 2020

In-Text Citation: (Sulaiman, Harun, Salleh, Ananthan, Wong, Mohaiyadin, Jaid, 2020).

To Cite this Article: Sulaiman, A., Harun, R., Salleh, M. Z., Ananthan, S., Wong, W. L., Mohaiyadin, N. M. H., Jaid, S. D. A. (2020). An Overview of the Malaysian Defence Industry and Way Forward. International Journal of Academic Research in Business and Social Sciences. 10(8), 1076-1083.

Copyright: (c) 2020 The Author(s)

Published by Human Resource Management Academic Research Society (www.hrmars.com)

This article is published under the Creative Commons Attribution (CC BY 4.0) license. Anyone may reproduce, distribute, translate and create derivative works of this article (for both commercial and non-commercial purposes), subject to full attribution to the original publication and authors. The full terms of this license may be seen

at: http://creativecommons.org/licences/by/4.0/legalcode

Vol. 10, No. 8, 2020, Pg. 1076 - 1083

Full Terms \& Conditions of access and use can be found at http://hrmars.com/index.php/pages/detail/publication-ethics 


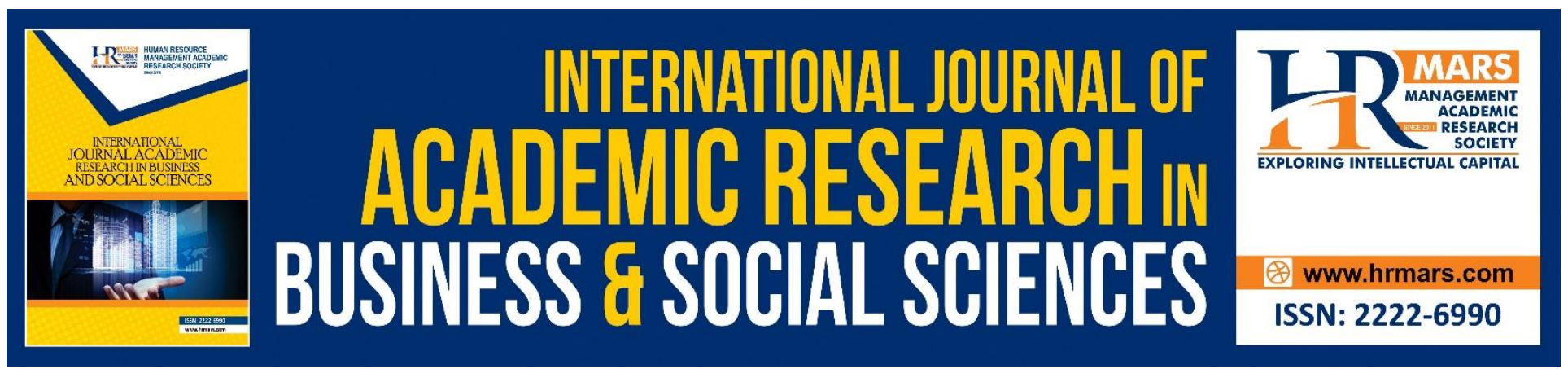

\title{
An Overview of the Malaysian Defence Industry and Way Forward
}

\author{
Amirudin Sulaiman ${ }^{1}$, Ruhanas Harun ${ }^{1}$, Mohd Zaini Salleh², \\ Ananthan, S. ${ }^{3}$, W. L. Wong ${ }^{4}$, Norlaila Mazura Hj. Mohaiyadin ${ }^{5}$, \\ Syafina Darlila Ahmad Jaidi ${ }^{6}$ \\ National Defence University of Malaysia (UPNM), Malaysia
}

\begin{abstract}
The aims of this study are: (1) To arrive at an overview of the Malaysian defence industry development since its inception and (2) To identify the challenges faced and its future development. This study applies a content analysis from related secondary sources for both aims with interviews conducted of two defence industry players to further assists the issues faced by the Malaysian defence industry. Malaysia can be considered a 'third-tier' arms producing country which is relatively 'low tech'. The development of the Malaysian defence industry began with maintenance and repairs in the aerospace industry and has grown into other areas such as weapons, information and communication technology, automotive and maritime. Its defence industry is faced with many challenging issues in furthering its development. The research is to analyse these issues and to provide practical and functional recommendations to further enhance the Malaysian defence industry and its defence self-reliance. The Malaysian government needs to refine a strategy in a holistically manner involving all the interested parties for the future needs of the country's security and defence; and aligning it with the necessary capabilities development of the Malaysian Armed Forces that can assuredly safeguard the country's sovereignty and integrity, and the country's survivability in times of major powers conflicts. The effort by the government to produce a defence white paper is lauded that may assist in overcoming the many challenging issues faced by the Malaysian defence industry.
\end{abstract}

Keywords: Malaysian Defence Industry, Defence Self-reliance, Malaysian Armed Forces, Strategy, Defence.

\section{Introduction}

According to Bitzinger's classification of a country's defence industry, Malaysia can be categorised as a 'third-tier' arms producing country where its defence industry is only capable of producing arms which is relatively 'low tech' and can only produce small arms, ammunitions, armoured vehicles and small sized ships including small arms licensed production such as rifles, and putting together imported parts for specific military equipment such as helicopters and armoured vehicles (Bitzinger, 
2015). Countries in the 'second tier' are countries that have built up an indigenous defence industry which is quite substantive and sophisticated and capable of designing, developing and manufacturing their own weapons systems and such countries include Japan, Indonesia, Singapore, South Korea and Taiwan (Bitzinger, 2015). The 'first tier' countries are those which have the capacity and capability to produce locally their own weapons systems such as the US, the UK, France and Germany (Balakrishnan \& Matthews, 2009). There is still a lacking in research for the Malaysian defence industry's development since its initial beginnings in 1976 in the aerospace sector. Thus, this paper intends to provide an overview of the challenging issues faced by the Malaysian defence industry development and to contribute towards the much needed literature in this area.

\section{The Development of the Malaysian Defence Industry}

The Malaysian Defence Industry began in 1976 with the aerospace industry in aircraft repair and overhaul depot (Balakrishnan, 2008) and has since grown into other areas such as weapons, information and communication technology (ICT), automotive, aerospace and maritime. Its growth is much related to the acquisitions of military equipment made by the Malaysian Armed Forces (MAF) through its strategic developmental plan which is known as the $4^{\text {th }}$ Dimension Malaysian Armed Forces Strategic Plan (4D MAF) (Daud, 2017). Prior to 1989, the MAF focused much of its activities in containing the threat of communist insurgency and was the first country to successfully overcome such a threat. However, with a change in its strategic direction after 1989, it dawned on the government to transform the MAF into a modern conventional force to deal with external threats. The economic growth experienced by the country after the 1990s provided the means for the government to procure more modern weapon platforms with the navy and air force being provided with greater roles to further support the army roles and tasks.

To further the development of the Malaysian defence industry landscape, the then Most Honourable Prime Minister Dr. Mahathir Mohamad provided the long term plan of making Malaysia a fully developed nation via its Vision 2020 goals. It is via this vision that technology transfers and offset programmes were introduced in the defence equipment acquisitions from foreign countries (Balakrishnan \& Matthews, 2009). This was done presumably with the understanding of the limitations faced by the country with regard to its capabilities and capacity to produce technologically advanced weapons platforms. It is also to further contribute towards defence self-reliance for the country (Balakrishnan \& Matthews, 2009; Bitzinger, 2015).

After 1989 and prior to the 1997 Asian Financial Crisis, the country experienced unprecedented economic growth and this helped boost the government program to invest in education. As a result, more of its populace were provided with the necessary skills and knowledge that has contributed towards the growth of the country's defence industry. A simple verification can be made is by looking at the improvements in the literacy rate in Malaysia where in 1991, which was about $83 \%$ and by 2010 it has improved to about 93\% (The Global Economy, 2019) and the number of university enrolment were 3.82\% in 1979 and 44.12\% in 2016 (The Global Economy, 2019).

\section{Malaysian Defence Industry Challenging Issues}

Despite the success of Malaysia in developing its defence industry and its contribution to the country's economic landscape, its progress has been curtailed by challenging issues, one of which is 
INTERNATIONAL JOURNAL OF ACADEMIC RESEARCH IN BUSINESS AND SOCIAL SCIENCES Vol. 10, No. 8, 2020, E-ISSN: 2222-6990 @ 2020 HRMARS

the lack of the government's clear guidance for the future strategic direction of the industry. Balakrishnan posited the concerns on the effectiveness on the part of the government in implementing the defence industry policy development, increasing the local content of the equipment in the MAF as most of it is still sourced from outside the country particularly from the Original Equipment Manufacturer (OEM), minimal research and development (R\&D) activities or export opportunities, the reluctance of OEMs to share its technology for fear of additional competition, the inability of local companies to possess the necessary capabilities and capacities and it is claimed that the Malaysian Armed Forces (MAF) is reluctant with locally produced product and services (Balakrishnan, 2008).

Malaysia was also affected by the Asian Financial Crisis with a downturn in its economic performance and thus affected its national income or Gross Domestic Product (GDP). The value of the Ringgit depreciated and this meant that imported goods including military equipment were getting more expensive. Relying on foreign manufacturers on the acquisitions of increasingly sophisticated and technologically advanced weapons platforms for the MAF will mean more funds will be needed for such ventures. Thus, it was wise on the part of the government to further develop the defence industry to add further the money value for such ventures and providing opportunities for its growth. To further develop the Malaysian defence industry, the government established the Malaysia Industry Council for Defence, Enforcement and Security (MIDES) in August 1999 and restructured it in March 2010 (Malaysia Defence Directory, 2019). However, how far the contributions of MIDES towards the development of the Malaysian defence industry can still be debated. Balakrishnan posited that the government lacks in providing a clear strategic guidance for the industry (Balakrishnan, 2008). This issue may arise from the disconnectivity in the relationship on the security and defence needs of the country and translating it into the needs in the development of the defence industry.

\section{Other Challenging Issues}

In a recent feedback from a selected Malaysian defence industry's players, there is a need to seriously remodel the structure and organisation of its landscape to provide further impetus for its relevancy, continuity and sustainable development. They are suggesting that a restructure and reorganisation of the industry needs to be relooked into as it was perceived that there is a 'stop-go' implementation of the defence development policy, for example, exclusive product rights that was given by an OEM was not further exploited and acquisitions made after were with differing OEMs. It is a waste of the defence industry talent with such a policy, for example, previous ship designers have to be retrenched and new ones are to be employed. As such the sustainability of the industry stops once the product is operational in the MAF. It was suggested that the government should exploit on the rights given in the technology transfer to produce more of the equipment but with new military technologies. Additionally, it is a logistical challenge for logisticians to maintain these differing OEM equipment as they have to come up with the additional human resource capital to undertake upgrades, maintenance, overhaul and repairs.

Among the feedback received from these industry players are that the procurement process is dealt with by 'agents' instead of direct negotiations with them. There are instances where products were developed with much investments by the defence companies but the Ministry of Defence (MOD) nor 
INTERNATIONAL JOURNAL OF ACADEMIC RESEARCH IN BUSINESS AND SOCIAL SCIENCES

Vol. 10, No. 8, 2020, E-ISSN: 2222-6990 @ 2020 HRMARS

the MAF were interested in acquiring the products developed and resulted in wasted $R$ \& $D$ investments.

Competition among established defence companies against the smaller and newly established defence companies is not put on a level playing field. Smaller and newly formed defence companies may not have strict regulations with minimal aspects of security, low turnover and lower pricing as compared to well established defence companies' adherence to regulations of a private company with higher products costs. Additionally, very few defence companies have a comprehensive vendor policy as compared to their counterparts of the small and newly formed defence entities. The consequences of such actions is not only the loss of well- trained human capital and the related vendors as they are dependent on the product when it is still in the production stage and within the period of contractual obligation. Once the product is operational in the MAF (all contractual obligations are met and no further acquisitions are made of the same product), these technicians particularly the product designers need to be laid off and similarly with the related vendors. Such situations are simply a waste of good talent for the development and enhancement of the defence industry and unnecessary sufferings faced by those who are laid off in such circumstances.

\section{Offsets Challenges in the Malaysian Defence Industry}

The issues and challenges in offsets are (Balakrishnan \& Matthews, 2009)

The difficulty of verifying the contractual obligations that has actually been realised. An example given by Balakrishnan \& Matthews is the challenge to prove that counter-purchase contracts have actually contributed towards existing commodities sales.

The OEMs are reluctant to provide technology transfers due to the expensive R\&D incurred and the perception that developing countries like Malaysia do not have the capacity nor the capability to achieve defence reliance. Thus, the country's defence industry is unable to develop beyond local maintenance, repair and overhaul capability.

The advanced weapon systems acquired are from differing countries that have contributed towards the many technical and logistical problems faced by both the MAF and the local defence industry. The differing technical standards and specifications of these systems have also resulted inefficiencies in its integration and interoperability across the MAF.

The diversified acquisitions made by Malaysia can contribute towards increased costs because of the frequent adaptation needs of the different OEMs technological processes. Different supplier will require different infrastructure and manufacturing equipment and the fear by OEMs of their technology being compromised to competitors. Most of the offsets involved maintenance, repair and overhaul activities while manufacturing and logistics activities are very small.

The reliance issue on foreign sources of technology, components, parts and process machinery by offset recipients that is seen to be a failure with regard to the provision of the necessary related economic activities for the local defence industry. 
INTERNATIONAL JOURNAL OF ACADEMIC RESEARCH IN BUSINESS AND SOCIAL SCIENCES

Vol. 10, No. 8, 2020, E-ISSN: 2222-6990 @ 2020 HRMARS

The failure of offsets programmes in the promotion of $R \& D$ activities where $R \& D$ expenditures by Malaysian defence companies is at a minimal level with the government being blamed for not providing the appropriate incentives to promote R \& D investments initiatives.

The cost-effectiveness of technology transfer is not proven due to institutional and bureaucratic challenges. The issue of intellectual property rights made it difficult for Malaysia in sourcing technology from other developing suppliers. Additionally, any sales to be made require the approval of OEMs and to abide with the US International Trade in Arms Regulation.

Malaysia's offsets performance major deficiency is its inability to create job opportunities where local jobs creation is very minimal and most of the new jobs created is focussed on the low-end technology activities.

\section{Way Forward}

These challenging issues faced by the Malaysian Defence Industry can be relooked with new creative and innovative ideas which can be implemented with boldness and vigour. It would make sense if a simple comparative study is undertaken on how Singapore was able to develop their defence industry successfully. Singapore defence companies are owned by Temasek Partners (2018), Singapore's government investment agency. Thus, when the defence companies are directly under the government, it provides the defence industry with a clear strategic outlook and guidance and were able to undertake effective $R \& D$, development of new technologies required for their armed forces and contributed with sales of their products to other countries. It can be deduced that when there is a government participation at the highest level, its defence industry is clearly guided towards its national defence and security interests. This provides a double edged sword strategy that benefits not only its armed forces but also its national economy.

Such a venture would be able to provide a holistic strategic approach to not only align the defence and security needs of the country but also involve the development of its defence industry such as the human capital needed by making the relevant higher learning institutions as partners in R \& D and producing the necessary skills needed to sustain the continuity of their defence industry. Additionally, many of the work force in its defence companies and institution of higher learning is captured from the personnel of the Singapore's Armed Forces, as such the work force understands the need for the continued assurance of the country's defence and security. The success story of the Singapore defence industry can also be deduced that besides the needed manpower from institutions of higher learning, the necessary skills at the technical level is also developed in parallel to ensure the manpower needs of the defence industry is managed from the ground-up.

\section{Malaysian Defence Industry Development Recommendations}

The MAF capabilities needed for the future war is to ensure that the country's land, maritime and airspace borders are assured. However, the current uncertainty in the international strategic environment, Malaysia would be better prepared if the current tensions between major powers could escalate into a nuclear war which can affect our national survival. Also, there is a need for collaboration with all the related agencies be it the National Security Council, Khazanah Nasional Berhad, the related government ministries and agencies including the MAF, partners in the defence 
INTERNATIONAL JOURNAL OF ACADEMIC RESEARCH IN BUSINESS AND SOCIAL SCIENCES Vol. 10, No. 8, 2020, E-ISSN: 2222-6990 @ 2020 HRMARS

industry, the private sector and learning institutions to come up with a practical and pronounced approach to overcome the many challenging issues faced.

Creating opportunities of converting the types of military production into alternative production such as Poland's experiences with the conversion of ammunition and anti-tank production to farm tractors (Hartley, 1996). Thus, the experiences gained by other countries of furthering the development of their defence industry to include non-military products can be gained via further research or collaboration with such friendly countries.

Hartley posited that the economics of standardisation can contribute towards increasing the efficiency of maintenance and training of military equipment (Hartley, 1996). He provided the comparison of the former Warsaw Pact armed forces and Russia. Thus, to further enhance the capability of the MAF, there is a need to reduce the variety of types and classes of weapons that will assist in the reduction of logistical problems faced without compromising MAF's operational capabilities to ensure the sovereignty and integrity of the country. This is a niche area of opportunity that the Malaysian defence industry can exploit in assisting the future needs of the MAF.

Increasing investments in $R$ \& $D$ that is practical and functional which holistically covers the defence and security needs of the country. The government needs to play a greater role in providing the necessary and required incentives to create such an environment. Where applicable, new technology developed for the MAF can also be practically converted into other practical commercial products that can invigorate further domestic consumption and economic activities.

It is a challenge to actually keep pace with the development of technology for Malaysia as it does not have the capacity nor the capability for furthering its defence industry development as that of even the 'second-tier' countries such as Indonesia or Singapore. Thus, there is a need to adjust and identify practical areas that the country already or in the process of acquiring specific technologies in the development of its defence industry that can also has a multiplier effect of commercialisation in nonmilitary areas.

\section{Conclusion}

It is with great expectation that the Malaysian government could wisely strategise a remodelling and reorganisation of the defence industry to make it more relevant to the future defence and security needs of the country. This strategy needs to be realised quickly so that the many challenging issues can be facilitated judiciously that will not only be beneficial to the defence and security of the country, but also contributing towards the national economy by the creation of more jobs opportunities. It can also contribute positively to make Malaysia attain an acceptable degree of self-reliance for its defence and security needs; and will add value towards a more sustainable development for its defence industry. Additionally, the strategy or strategies formulated should also contribute towards an increased operational capability of the MAF and making the necessary early preparations in a conflict between the major powers (if it happens) for the survivability of the country. The effort of a defence white paper by the Malaysian government may just be the needed impetus to address the many issues faced by the Malaysian defence industry for its future development. The defence white paper should also be strategically aligned with the country's survivability in times of major powers 
INTERNATIONAL JOURNAL OF ACADEMIC RESEARCH IN BUSINESS AND SOCIAL SCIENCES Vol. 10, No. 8, 2020, E-ISSN: 2222-6990 @ 2020 HRMARS

conflict, its defence and security needs. It may just be the avenue to alleviate Malaysia's defence industry into the 'second tier' of arms producing countries the likes of Indonesia or Singapore.

\section{Acknowledgement}

My heartfelt gratitude and appreciation to Professor Ruhanas Harun who together co-wrote this study and all my co-researchers for their tireless assistance and comments in the successful write-up of this study. Also, to the Dean, Faculty of Defence Studies and Management; and the Vice Chancellor, National Defence University of Malaysia itself for their insistence towards research contributions for the university.

\section{Corresponding Author}

Amirudin Sulaiman, National Defence University of Malaysia, Kem Perdana Sungai Besi, 57000 Kuala Lumpur, Malaysia, Tel: +60193247800, Email: amirudinsul@gmail.com

\section{References}

\section{Book Chapters}

Balakrishnan, K., \& Matthews, R. (2009). The role of offsets in Malaysian defence industrialisation. Defence and Peace Economics, 20(4), 341-358.

Bitzinger, R. A. (2015). Defense industries in Asia and the technonationalist impulse. Contemporary security policy, 36(3), 453-472.

Hartley, K. (1996). Defence industries adjusting to change. Defence and Peace Economics, 7(2), 169184.

\section{Journal/Serials}

Balakrishnan, K. (2008). Defence industrialisation in Malaysia: development challenges and the revolution in military affairs. Security challenges, 4(4), 135-155.

\section{Online Sources}

Daud, N. (2017), Malaysia World News, MAF Chief urges the public to join effort to combat terrorist group 'Daesh', https://www.malaysiaworldnews.com/2017/09/26/maf-chief-urges-the-publicto-join-effort-with-the-army-to-combat-terrorist-group-daesh/ accessed 20 Feb 2019.

Malaysia Defence Directory. (2019). http://defencemalaysia.com/listings/details/malaysia-industrycouncil-for-defence-enforcement-and-security-defence-industry-division-ministry-of-defencemalaysia.html accessed 20 Jan 19.

Temasek Partners. (2018) - National University of Singapore. http://nus.edu.sg/tdsi/about/partners.html. Accessed 17 Sep 2018.

The Global Economy.com. (2019), https://www.theglobaleconomy.com/Malaysia/Literacy_rate/ accessed 28 Jan 2019 and 29 Jan 2019. 